\title{
СУЧАСНИЙ СТАН, ПРОБЛЕМИ ТА ПЕРСПЕКТИВИ РОЗВИТКУ РИНКУ МАРКЕТИНГОВИХ СЕРВІСІВ УКРАЇНИ
}

\begin{abstract}
У статті проаналізовано актуальність використання різноманітних маркетингових сервісів та їх необхідність в умовах жорсткої конкуренції між виробниками продукції $i$ послуг. Наводиться класифікація маркетингових сервісів за інструментарієм, проаналізована динаміка розвитку ринку за останні декілька років. Досліджено основні групи проблем галузі, а також можливі шляхи їх вирішення.
\end{abstract}

Ключові слова: маркетинг, маркетинговий сервіс, послуга, ринок, проблеми діяльності, напрямки розвитку.

Постановка проблеми. У сучасних реаліях розвитку глобального і національного ринку зокрема - коли саме споживач є головним у «відносинах» 3 підприємством, вивчення його потреб і вміння їх задовольнити є основою успішного ведення бізнесу. Саме тому використання різноманітних маркетингових сервісів $\epsilon$ не тільки актуальним, але й необхідним моментом в умовах жорсткої конкуренції між виробниками продукції і послуг.

Термін «маркетинговий сервіс» з'явився порівняно недавно, і тому серед маркетологів ще не склалося єдиної думки, що ж він точно визначає. Нерідко під маркетинговим сервісом розуміють комплекс маркетингових завдань, який може бути переданий на постійне обслуговування спеціалізованій маркетинговій компанії [1].

Маркетингові сервіси допомагають виробляти товари, надавати послуги або проводити політику відповідно до вимог споживачів, підприємств і суспільства. Крім того, вони дозволяють значно знижувати різні види ризику (фінансові й комерційні), показують ставлення покупців до певних товарів або послуг, значно збільшують ефективність ринкових заходів.

Аналіз останніх досліджень і публікацій. Питання, присвячені маркетингу, маркетинговим дослідженням, маркетинговим комунікаціям їх цілі, завдання, напрями та процес здійснення вивчали такі провідні науковці як Ф. Котлер, В. Вонг, К. Нареш, Д. Сондерс, Гілберт А. Черчілль, Том Дж. Браун, та ін. [2,3].

Серед вітчизняних науковців, що займалися даною проблематикою та зробили суттєвий

(C) Лозовська Ганна Миколаївна, к.е.н., старший викладач, Одеська національна академія харчових технологій, м.Одеса, тел.: +380672970507, e-mail: aniko85@ukr.net внесок у розвиток окремих маркетингових сервісів в Україні можна виділити А.В. Войчак, С.С. Гаркавенко, А.Ф. Павленко, В.П. Пилипчук, Т.О. Примак, І.Л. Решетнікова, А.О. Старостіна, І.В. Лилик, О.В. Кудирко та ін.[4,5]. Однак, роботи здебільшого стосуються теоретичних i практичних напрямів використання маркетингових сервісів i не розглядають його як окремий вид бізнесу. Саме тому оцінка сучасного стану, проблем та перспектив розвитку ринку маркетингових сервісів в Україні набуває актуальності.

Формулювання цілей статті. Метою статті $\epsilon$ оцінка сучасного стану, проблем та перспектив розвитку ринку маркетингових сервісів України.

Опис основного матеріалу дослідження. Досліджуючи сучасний стан, проблеми та перспективи розвитку ринку маркетингових сервісів України, перш за все необхідно дати визначення поняттю «маркетинговий сервіс».

$\mathrm{y}$ значенні «окрема послуга» під маркетинговим сервісом розуміють будь-який промоушен товару або послуги, що надається спеціалізованою маркетинговою компанією на умовах аутсорсингу. У цьому випадку до маркетингового сервісу відносять певну маркетингову діяльність підприємства, пов'язану зі здійсненням контактів зі споживачами. Як правило, у число маркетингових сервісів можуть бути включені практично всі маркетингові завдання за винятком безпосередніх продажів [1].

На практиці розрізняють наступні види маркетингових сервісів (послуг) [1]:

- Подійний маркетинг (event marketing) це організація ділових і розважальних заходів, включаючи також благодійні, культурні й соціальні акції;

- Цифровий маркетинг (digital marketing) - це маркетинговий сервіс, заснований на використанні електронних комунікаційних 
технологій. Найчастіше цифровий маркетинговий сервіс базується на використанні технологій стільникового зв'язку й Інтернету;

- Просування продукції (trade promotion) - це рекламні й маркетингові промоакції в точках продажів;

- Директ-Маркетинг (direct marketing) маркетинговий сервіс, який припускає пряме спілкування 3 теперішніми й потенційними клієнтами за допомогою пошти, Інтернету або телефону ( колл-центри);

- Маркетингові дослідження (marketing research) - маркетинговий сервіс, завдяки якому замовник одержує достовірну інформацію про стан ринку в досліджуваний період, зокрема, розміри ринку, динаміку його розвитку, ключових гравців і провідні торговельні марки;

- Консалтинг в галузі маркетингу, включаючи оперативний маркетинг i стратегічне

діяльності;

- Зв'язки із громадськістю (PR);

- Організація виставкової діяльності.

Основним джерелом інформації для аналізу ринку українських маркетингових сервісів $\epsilon$ Міжнародна Асоціація Маркетингових Ініціатив (MAMI) - офіційна галузева організація ринку маркетингових сервісів, яка поєднує близько 50 агентств [6]. Створена 19 травня 2006 року. МАМІ здійснює ряд проектів: публікує прогнози розвитку ринку, проводить дослідження, складає рейтинги агентств маркетингових сервісів по креативності й доходам, організовує освітні заходи для досвідчених і починаючих фахівців галузі та ін.

MAMI надає класифікацію маркетингових сервісів за інструментарієм таким чином (табл. 1).

Таблиця 1

Класифікація маркетингових сервісів за інструментарісм [6]

\begin{tabular}{|c|c|c|c|}
\hline \multirow{2}{*}{$\begin{array}{c}\text { Види } \\
\text { маркетингових } \\
\text { сервісів } \\
\end{array}$} & \multirow{2}{*}{ Перелік послуг } & \multicolumn{2}{|c|}{ Опис } \\
\hline & & включає & Не включас \\
\hline 1 & 2 & 3 & 4 \\
\hline \multirow{4}{*}{ 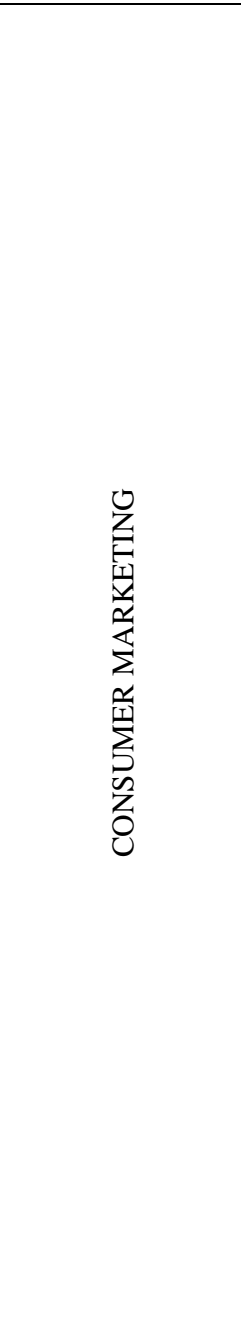 } & $\begin{array}{l}\text { Розробка стратегії програм } \\
\text { по стимулюванню продажів. } \\
\text { Розробка національних і } \\
\text { локальних програм по } \\
\text { стимулюванню продажів: } \\
\text { створення креативних } \\
\text { концепцій, матеріалів. } \\
\text { Підготовка, організація й } \\
\text { проведення польових робіт: } \\
\text { семплінги, дегустації, } \\
\text { подарунок за покупку, } \\
\text { розіграші/конкурси, збери й } \\
\text { одержи, поширення } \\
\text { інформаційних матеріалів, } \\
\text { консультування у полиць }\end{array}$ & 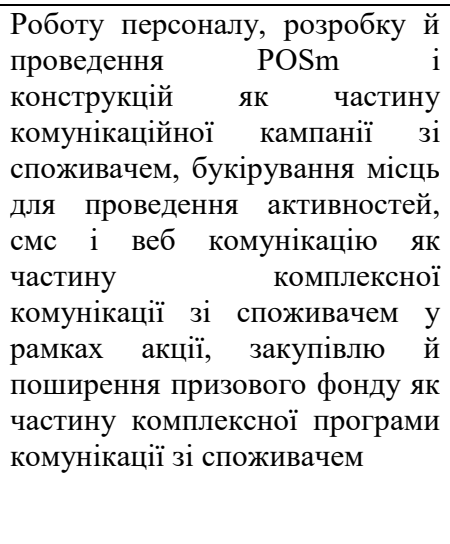 & $\begin{array}{l}\text { Технічні обсяги смс трафіка } \\
\text { компаній, що спеціалізуються на } \\
\text { наданні мобільних послуг, медіа } \\
\text { бюджети на розміщення } \\
\text { рекламної комунікації в } \\
\text { підтримку промо активності на } \\
\text { ТВ, радіо, транспорті й інших } \\
\text { медіа носіях, технічні обсяг } \\
\text { серійного проведення принт і } \\
\text { інших стандартних матеріалів, } \\
\text { сувенірів у якості продакшн } \\
\text { хауза, участь промоутерів у } \\
\text { політичних мітингах }\end{array}$ \\
\hline & & $\begin{array}{l}\text { Створення й просування промо- } \\
\text { сайтів, проведення } \\
\text { промоушенів, } \\
\text { баннерної реклами, розробока } \\
\text { соцмережами в } \\
\text { бренду, PR-підтримка акцій }\end{array}$ & $\begin{array}{l}\text { Підтримка роботи інтернет } \\
\text { магазинів, продаж через інтернет } \\
\text { товарів і послуг, створення й } \\
\text { підтримка ігрових сайтів (не в } \\
\text { рамках просування брендів), } \\
\text { інформаційних порталів, медійні } \\
\text { бюджети в інтернеті }\end{array}$ \\
\hline & & $\begin{array}{l}\text { Робота із блогерами, } \\
\text { модераторами, творцями й } \\
\text { розповсюджувачами контенту }\end{array}$ & \\
\hline & & $\begin{array}{l}\text { Мобільний маркетинг: } \\
\text { SMS/MMS/IVR/bluetooth } \\
\text { інтерактив у консьюмер промо, } \\
\text { розробки на базі мобільної } \\
\text { доповненої реальності, } \\
\text { двовимірного кодування, } \\
\text { геолокаційних інструментів, } \\
\text { створення мобільних сайтів, } \\
\text { додатків, рекламного медіа- } \\
\text { контенту й брендованих ігор } \\
\text { для мобільних платформ }\end{array}$ & $\begin{array}{l}\text { Продаж мобільного контенту, } \\
\text { SMS голосування в підтримку } \\
\text { TБ проектів, SMS трафік третіх } \\
\text { осіб, медійні бюджети } \\
\text { мобільного маркетингу }\end{array}$ \\
\hline
\end{tabular}




\begin{tabular}{|c|c|c|c|}
\hline & & & Продовжсення табл. 1 \\
\hline 1 & 2 & 3 & 4 \\
\hline \multirow{5}{*}{ 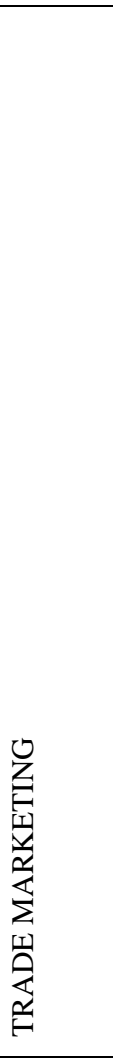 } & $\begin{array}{l}\text { Розробка рішень і стратегій в } \\
\text { галузі торговельного } \\
\text { маркетингу, дослідження в } \\
\text { pоздробі (Trade Marketing } \\
\text { Strategic Planning and } \\
\text { Marketing Audit): }\end{array}$ & $\begin{array}{l}\text { План кампанії й творча ідея по } \\
\text { активації продажів бренду; } \\
\text { політика категорійного } \\
\text { менеджменту; концепція } \\
\text { мерчендайзингу; функціонал POSm } \\
\text { і торговельного обладнання }\end{array}$ & \multirow{4}{*}{ 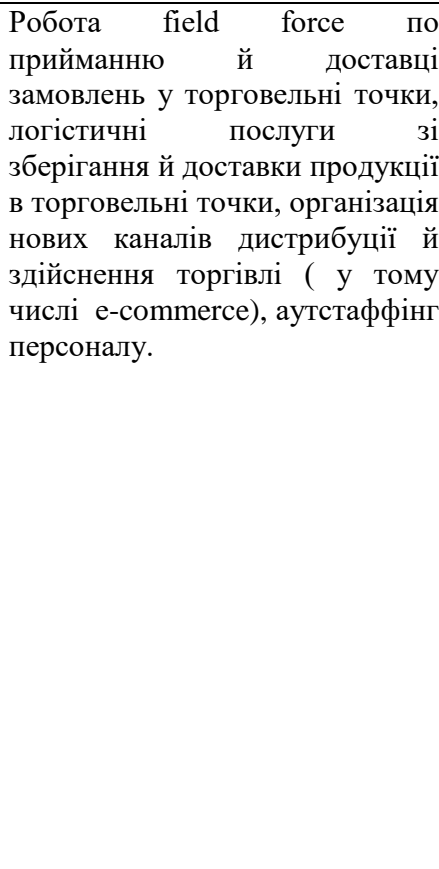 } \\
\hline & $\begin{array}{l}\text { Творча розробка ТМ- } \\
\text { комунікацій: }\end{array}$ & $\begin{array}{l}\text { Дизайн і копірайтинг } \\
\text { презентаційних матеріалів для } \\
\text { закупників; створення/оформлення } \\
\text { promo-расks i gift-packs; дизайн i } \\
\text { конструювання POSm i } \\
\text { торговельного обладнання; } \\
\text { розробка сувенірної продукції й } \\
\text { призів для мотиваційних програм }\end{array}$ & \\
\hline & $\begin{array}{l}\text { Програми стимулювання } \\
\text { продавців: }\end{array}$ & $\begin{array}{l}\text { Мотиваційні програми із призами } \\
\text { за виконання умов; Тренінги й } \\
\text { інформування продавців; } \\
\text { Проведення заходів для дилерів }\end{array}$ & \\
\hline & Польові роботи: & $\begin{array}{l}\text { Мерчендайзинг виділений i } \\
\text { сполучений, консультанти у } \\
\text { полиць, роздрібні моніторинги, } \\
\text { таємний покупець, перепис } \\
\text { торговельних точок, аутсорсинг } \\
\text { персоналу }\end{array}$ & \\
\hline & & $\begin{array}{l}\text { Мобільний маркетинг: } \\
\text { SMS/MMS/IVR/bluetooth } \\
\text { інтерактив у трейд промо, } \\
\text { створення мобільних сайтів, } \\
\text { додатків }\end{array}$ & \\
\hline \multirow{5}{*}{ 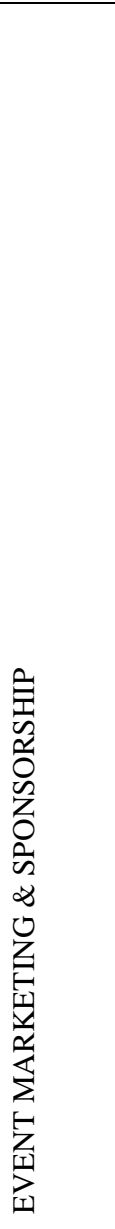 } & $\begin{array}{l}\text { Розробка концепції події й } \\
\text { реалізація }\end{array}$ & & $\begin{array}{l}\text { Non-media спонсорство, } \\
\text { концерти й фестивалі, які } \\
\text { проводяться в рамках шоу- } \\
\text { бізнесу, не на замовлення } \\
\text { окремої ТМ. Медійні бюджети } \\
\text { на анонсування заходів, } \\
\text { технічний букинг, } \\
\text { здійснюваний спеціалізованими } \\
\text { третіми особами (не прямо з } \\
\text { кінцевим замовником). }\end{array}$ \\
\hline & $\begin{array}{l}\text { Події ТМ для кінцевого } \\
\text { споживача }\end{array}$ & $\begin{array}{l}\text { Спеціальні події (Festivals, Road } \\
\text { Shows, Street Events, Test Drive); } \\
\text { подійний семплінг (Horeca); } \\
\text { флешмоби; присутність/активація } \\
\text { торговельної марки в } \\
\text { спонсорських, культурних, } \\
\text { благодійних, соціальних, } \\
\text { спортивних і інших програмах }\end{array}$ & \\
\hline & $\begin{array}{l}\text { Події ТМ для бізнес } \\
\text { споживача }\end{array}$ & $\begin{array}{l}\text { Корпоративні заходи (Conferences, } \\
\text { Seminars, Exhibitions, Presentations, } \\
\text { корпоративні свята) }\end{array}$ & \\
\hline & Experiential Marketing & $\begin{array}{l}\text { Інтерактивні інсталяції в рамках } \\
\text { заходів або в місцях скупчення ЦА } \\
\text { торговельних марок }\end{array}$ & \\
\hline & & $\begin{array}{l}\text { Мобільний маркетинг: } \\
\text { SMS/MMS/IVR/bluetooth } \\
\text { інтерактив в івентах, розробки на } \\
\text { базі мобільної доповненої } \\
\text { реальності, двовимірного } \\
\text { кодування, геолокаційних } \\
\text { інструментів, створення мобільних } \\
\text { сайтів, додатків, рекламного медіа- } \\
\text { контенту й брендованих ігор для } \\
\text { мобільних платформ }\end{array}$ & $\begin{array}{l}\text { Продаж мобільного контенту, } \\
\text { SMS голосування в підтримку } \\
\text { ТБ проектів, SMS трафік третіх } \\
\text { осіб, медійні бюджети } \\
\text { мобільного маркетингу }\end{array}$ \\
\hline
\end{tabular}




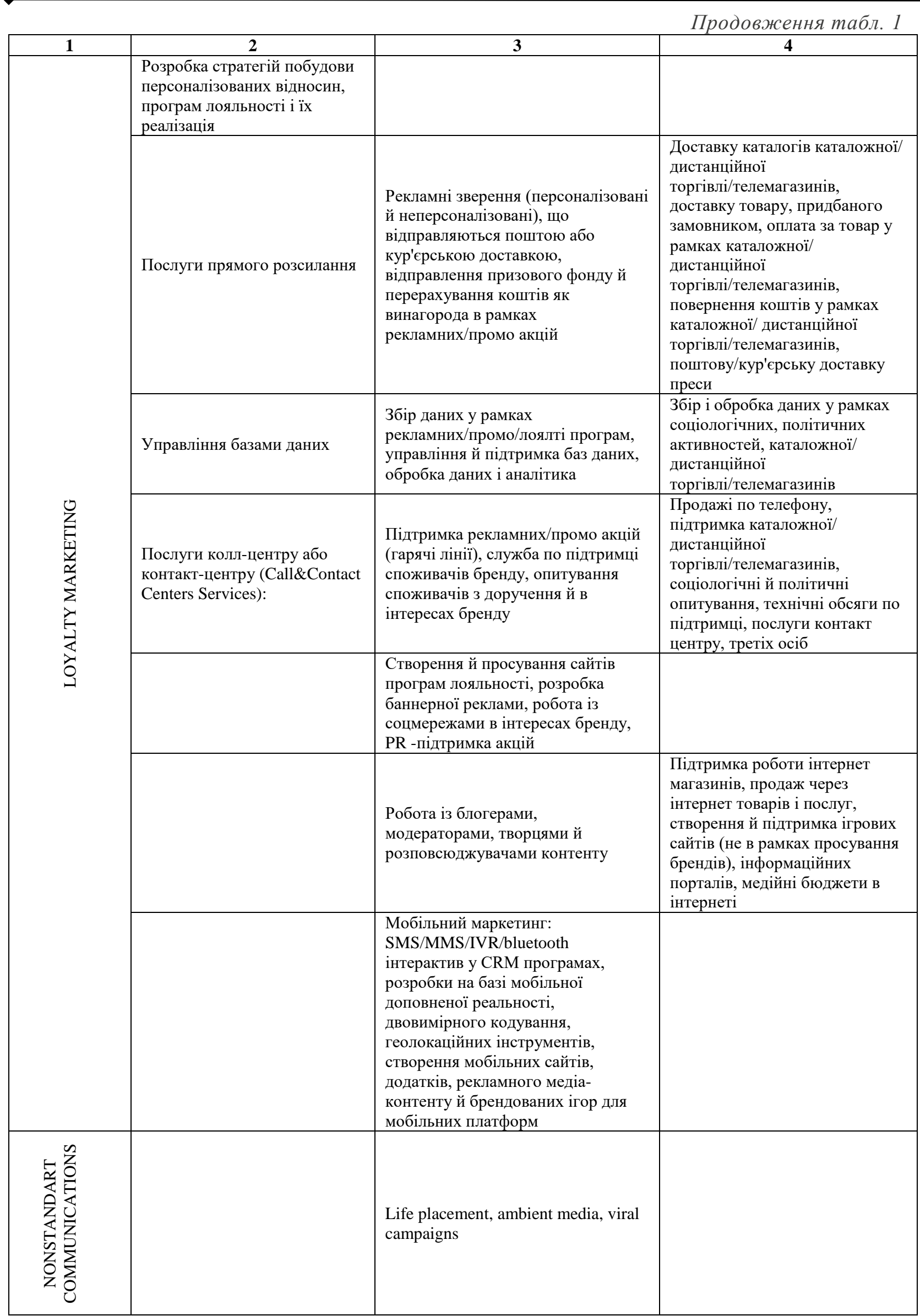


Ситуація на ринку маркетингових сервісів прямо залежить від економічного й політичного положення в країні.

Однак, якщо оцінювати картину в цілому, можна побачити, що не всі маркетингові сервіси розвивалися однаково (рис. 1,2) [7].
Як видно з рисунків 1,2 найбільш критичним для ринку був 2014 рік. Спостерігалося падіння майже по всім видам маркетингових сервісів що пов'язано 3 економічною i політичною кризою, втратою частини територій, низькою купівельною спроможністю і як наслідок зменшенням маркетинг-бюджетів.

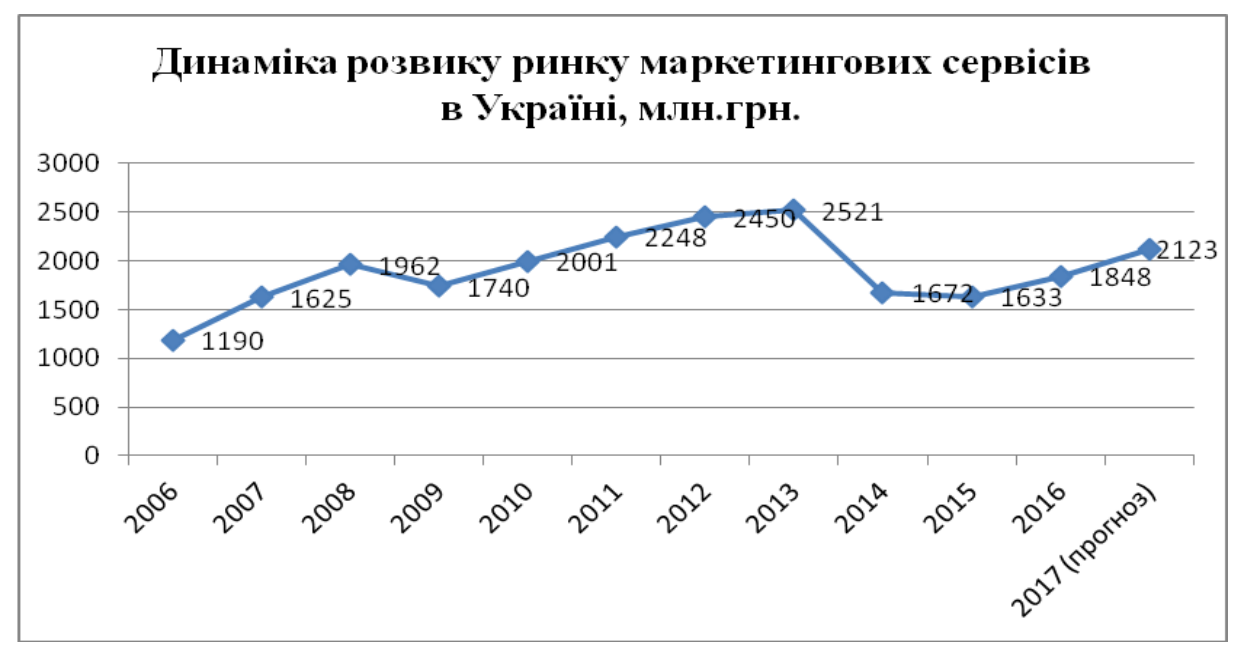

Рис. 1 Загальна динаміка розвитку ринку маркетингових сервісів в Україні, млнгрн [7]

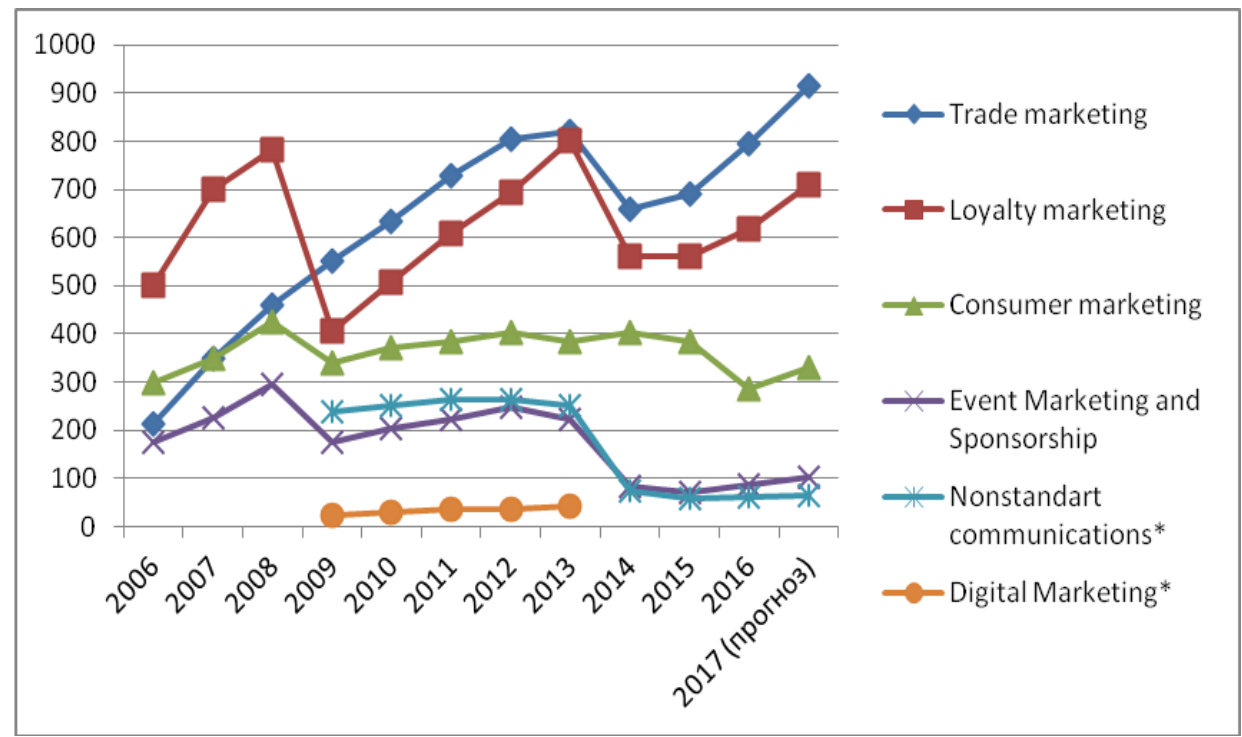

Рис. 2 Динаміка розвитку ринку окремих маркетингових сервісів в Україні, млнгрн[7]

* Деякі дані відсутні

Trade marketing, Consumer marketing сервіси, які прогнозовано дають швидкий результат незалежно від економічної ситуації в країні, розвиваються більш рівномірно, тоді як інші - Loyalty marketing, Event marketing, Nonstandart communications схильні до значних коливань у своєму розвитку, оскільки не дають такої швидкої грошової віддачі й вимагають значних фінансових витрат.

В 2016 році ринок показав ріст на 13\%. Частково цифра пояснюється інфляцією, але й об'єктивно активність рекламодавців стала набагато вищою: більше тендерів, більше реалізованих програм ніж в попередні два роки [3].

Якщо проаналізувати окремі сервіси - Trade marketing, Consumer marketing показали динаміку $+10-+15 \%$, Event marketing показав ріст на 20\% у порівнянні 32015 p. Дещо повільніший зріст показують Nonstandart communications (табл. 2) [7]. 
Таблиця 2

Обсяги ринку маркетингових сервісів 2014-2016 рр. та прогноз на 2017 р.

\begin{tabular}{|c|c|c|c|c|c|c|c|}
\hline Маркетингові сервіси & $\begin{array}{l}\text { Обсяг } \\
2014 \text { р., } \\
\text { млнгрн. }\end{array}$ & $\begin{array}{l}\text { Обсяг } \\
2015 \text { р., } \\
\text { млнгрн. }\end{array}$ & $\begin{array}{l}\% \\
\text { зміни } \\
2015 \text { до } \\
2014\end{array}$ & $\begin{array}{l}\text { Обсяг } \\
2016 \text { р., } \\
\text { млнгрн. }\end{array}$ & $\begin{array}{l}\% \\
\text { зміни } \\
2016 \text { до } \\
2015\end{array}$ & $\begin{array}{l}\text { Обсяг } \\
2017 \text { р., } \\
\text { млнгрн. }\end{array}$ & $\begin{array}{l}\% \\
\text { зміни } \\
2017 \text { до } \\
2016\end{array}$ \\
\hline $\begin{array}{l}\text { Обсяг ринку Маркетингових } \\
\text { сервісів } \\
\text { УСЬОГО }\end{array}$ & 1672 & 1633 & $-2,3 \%$ & 1848 & $13 \%$ & 2123 & $15 \%$ \\
\hline \multicolumn{8}{|l|}{ У тому числі: } \\
\hline $\begin{array}{l}\text { Trade marketing } \\
\text { (Мерчандайзинг, Trade } \\
\text { promo, Програми мотивації } \\
\text { й контролю персоналу) }\end{array}$ & 658 & 691 & $5 \%$ & 795 & $15 \%$ & 914 & $15 \%$ \\
\hline $\begin{array}{l}\text { Loyalty marketing (Mailing, } \\
\text { DB management, Contact- } \\
\text { Center) }\end{array}$ & 561 & 561 & $0 \%$ & 617 & $10 \%$ & 710 & $15 \%$ \\
\hline Consumer marketing & 293 & 249 & $-15 \%$ & 286 & $15 \%$ & 329 & $15 \%$ \\
\hline $\begin{array}{l}\text { Event Marketing and } \\
\text { Sponsorship }\end{array}$ & 85 & 72 & $-15 \%$ & 86 & $20 \%$ & 104 & $20 \%$ \\
\hline $\begin{array}{l}\text { Nonstandart communications } \\
\text { (life placement, ambient } \\
\text { media) }\end{array}$ & 75 & 60 & $-20 \%$ & 63 & $5 \%$ & 66 & $5 \%$ \\
\hline
\end{tabular}

Виходячи 3 таблиці 2 можна зробити висновок, що галузь зуміла адаптуватись до нових реалій i загалом спостерігається позитивна динаміка.
Однак за оцінками різних спеціалістів, для українського ринку маркетингових сервісів характерна низка проблем, а саме (рис.3):

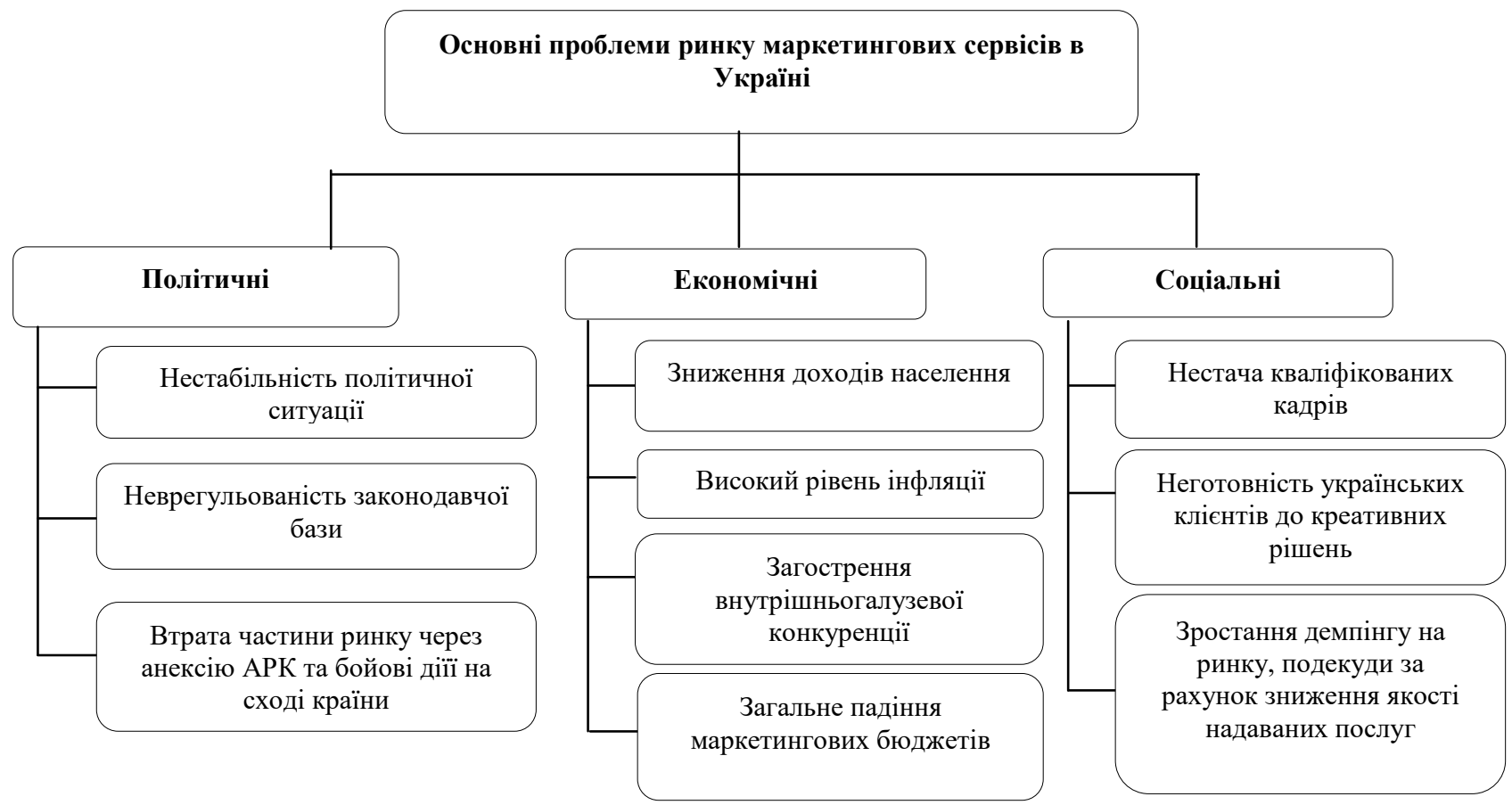

Рис. 3 Основні проблеми ринку маркетингових сервісів в Україні*

* Складено автором

Виходячи 3 рисунку видно, що основні проблеми умовно поділені на 3 види: політичні, економічні i соціальні. I якщо політичні i економічні проблеми $\epsilon$ зрозумілими для українського ринку i взаємопов'язані між собою, то соціальні проблеми потребують більшого уточнення:

- нестача кваліфікованих кадрів пояснюється тим, що існує істотний відтік креативних фахівців, насамперед візуальних 
спеціальностей: арт-директорів, дизайнерів. Вони йдуть у суміжні галузі - IT, зокрема у геймінг-студії, у західні мультиплікаційні проекти, а також у цілому на фріланс на закордонні ринки. Причина відтоку - грошова. В IT-проектах оплата прив'язана до валюти на противагу оплаті в гривнях без індексації або 3 мінімальною індексацією в українських агентствах. Однак бракує не тільки їх - нестача кваліфікованих кадрів спостерігається і секторі Event Marketing, маркетингових досліджень та ін.[8];

- зростання демпінгу на ринку, подекуди за рахунок зниження якості надаваних послуг. Відбувається укрупнення гравців рекламного ринку, тому що невеликі агентства не витримують умов післяплат від клієнтів. Великі гравці цінують свою працю, надають якісні послуги, і все-таки поводяться більш етично в порівнянні 3 невеликими «кишеньковими» агентствами [8];

- неготовність українських клієнтів до креативних рішень пояснюється тим, що клієнт часто сам не до кінця розуміє чого він хоче, або всі креативні задумки стикаються 3 обмеженим бюджетом [9].

Всі ці проблеми значно сповільнюють зростання українського ринку маркетингових сервісів. Однак, існує безліч ефективних рішень, які дозволять агентствам не тільки вдало конкурувати на ринку, але й розширити його. Серед таких рішень доцільними є:

Підвищення внутрішньофірмових стандартів якості з обслуговування клієнтів, розробка галузевих стандартів;

\section{Підвищення}

кваліфікації

працівників маркетингових агентств за допомогою різноманітних курсів, семінарів, тренінгів;

Проведення

різноманітних конкурсів і створення рекрутингових служб 3 пошуку талановитої і креативної молоді;

$>$ Постійний моніторинг якості маркетингових послуг, що надаються клієнтам.

Дані заходи істотно поліпшать ситуацію як в окремих агентствах, так i на ринку маркетингових сервісів в цілому, дозволяючи підвищити стандарти обслуговування клієнтів та якість надаваних послуг.

Висновки та перспективи подальших досліджень. В умовах економічної і політичної нестабільності, а також жорсткої конкуренції маркетингові сервіси допомагають істотно поліпшити продажі товарів, зрозуміти потреби споживачів i суспільства, визначити ї ставлення до окремих товарів та послуг. Саме від ринку маркетингових сервісів залежить успішна діяльність багатьох секторів економіки.

Проте на ринку існує низка проблем, які іноді заважають надавати клієнтам посправжньому якісні послуги. Підвищення кваліфікації працівників, пошук талановитої молоді, розробка галузевих стандартів якості надаваних послуг призведе до загального зростання ринку маркетингових сервісів України. Перспективою подальших досліджень $\epsilon$ оцінка розвитку і ефективності діяльності окремих маркетингових сервісів України.

\section{ПЕРЕЛІК ВИКОРИСТАНИХ ДЖЕРЕЛ}

1. AS Marketing. Комплексный маркетинг и стратегический консалтинг. [Електронний ресурс]. - Режим доступу: http://www.asmarketing.ru/slovar-marketologa/marketingovyiy-servis.html

2. Котлер Ф. Основы маркетинга. 5-е европейское изд / Ф. Котлер, Г. Армстронг - М.: Вильямс, 2015. $752 \mathrm{c}$.

3. Гилберт А. Черчилль, Том Дж. Браун. Маркетинговые исследования - 5-е изд. / Черчиль А. Гилберт, Браун Дж. Том; пер. с англ. под ред. Г. Л. Багиева. - СПб.: Питер, 2007. - 704 с.

4. Гаркавенко С.С. Маркетинг. Підручник для студ. екон. спец. вищ. навч. закл. - 4-е. вид., доп./ С.С. Гаркавенко - К.: Лібра, 2006. -717 с.

5. Маркетингові дослідження: кейси та ситуаційні вправи / І. В. Лилик, О. В. Кудирко. - К.: КНЕУ, 2010. $-313 \mathrm{c}$.

6. МАМИ. Стандарты отрасли. Классификация по инструментарию. [Електронний ресурс]. - Режим доступу: http://mami.org.ua/classification

7. МАМИ. Предновогоднее. Итоги 2016, прогноз 2017 - [Електронний ресурс]. - Режим доступу: http://mami.org.ua/news/mami-news/Prednovogodnee-Itogi-216-prognoz-217

8. В Украине уменьшился рынок маркетинговых сервисов. [Електронний ресурс]. - Режим доступу: http://news.eizvestia.com/news-markets/full/717-v-ukraine-umenshilsya-rynok-marketingovyh-servisovissledovanie

9. Ивент-индустрия в Украине: проблемы, перспективы, возможности. [Електронний ресурс]. - Режим доступу: https://www.work.ua/articles/guest/1245/ 


\section{REFERENCES}

1. AS Marketing. Kompleksnyj marketing i strategicheskij konsalting. [Complex marketing and strategic consulting]. www.asmarketing.ru. (n.d.). Retrieved from: http://www.asmarketing.ru/slovarmarketologa/marketingovyiy-servis.html [in Russian].

2. Kotler, F., \& Armstrong, G. (2015). Osnovy marketinga [Principles of Marketing] (5nd ed.). Moscow: Vil'jams [in Russian].

3. Gilbert A. Churchill \& Tom J. Brown. (2007). Marketingovye issledovanija [Basic Marketing Research]. G. L. Bagiev (Ed.) Saint Petersburg: Piter [in Russian].

4. Garkavenko S.S. (2006). Marketynh [Marketing] (4nd ed.). Kyiv: Libra [in Ukrainian].

5. Lylyk, I. V., \& Kudyrko, O. V. (2010). Marketynhovi doslidzhennya: keysy ta sytuatsiyni vpravy [Marketing researches: cases and Situation exercises]. - Kyiv: KNEU [in Ukrainian].
6. MAMI.
Standarty
otrasli.
Klassifikacija
po instrumentariju.
[IAMI

Standards of industry. Classification of tools]. mami.org.ua. (n.d.). Retrieved from: http://mami.org.ua/classification [in Russian].

7. MAMI.

Prednovogodnee.

Itogi

2016,

prognoz

2017.

[IAMI.

Before New Year. Results 2016, prognosis 2017]. mami.org.ua. Retrieved from: http://mami.org.ua/news/maminews/Prednovogodnee-Itogi-216-prognoz-217 [in Russian].

8. V Ukraine umen'shilsja rynok marketingovyh servisov. [The market of marketing services diminished in Ukraine]. news.eizvestia.com. Retrieved from: http://news.eizvestia.com/news-markets/full/717-v-ukraine-umenshilsya-rynok-marketingovyh-servisovissledovanie [in Russian].

9. Ivent-industrija v Ukraine: problemy, perspektivy, vozmozhnosti. [Industry of events is in Ukraine: problems, prospects,possibilities]. www.work.ua (n.d.). Retrieved from: https://www.work.ua/articles/guest/1245/ [in Russian]. 